\title{
Politics, Privileges, and Loyalty in the Zimbabwe National Army
}

\author{
Godfrey Maringira
}

\begin{abstract}
In postcolonial Africa, the military has become an actor in politics, often in ways that can be described as unprofessional. This paper focuses on the manner in which the Zimbabwean National Army (ZNA) has become heavily politicized since independence, directly supporting the regime of President Robert Mugabe while denigrating the opposition political party. The military metamorphosed, to all intents, into an extension of President Mugabe's political party, the ZANU-PF. I argue that even though the military is expected to subordinate itself to a civilian government, the ZNA is highly unprofessional, in- and outside the army barracks. The ways in which politics came to be mediated by army generals, as "war veterans" serving in the military, directly influenced not only how soldiers who joined the army in postindependence Zimbabwe were promoted and demoted, but how they lived their lives as soldiers in the army barracks. This article is based on fifty-eight life histories of army deserters living in exile in South Africa.
\end{abstract}

Résumé: Dans l'Afrique postcoloniale, l'armée est devenue un acteur politique, qui peut être souvent décrit comme non professionnel. Cet article se focalise sur la manière dont l'armée nationale du Zimbabwe (ZNA) est devenue fortement politisée depuis l'indépendance, se transformant, de fait, comme une extension du parti politique du Président Robert Mugabe, le ZANU-PF et dénigrant l'opposition. Faisant appel à des histoires vécues de cinquante-huit déserteurs de l'armée en exil en Afrique du Sud, cet article décrit les manières dont les affaires politiques au Zimbabwe sont médiés par les généraux de l'armée, comme "vétérans de guerre » servant dans l'armée. Cette situation influence directement non seulement comment les soldats qui ont rejoint l'armée au Zimbabwe postindépendance sont promus et rétrogradés, mais aussi comment ils vivent leur vie comme soldats dans les casernes de l'armée.

African Studies Review, Volume 60, Number 2 (September 2017), pp. 93-113

Godfrey Maringira is a VolkswagenStiftung postdoctoral fellow based at the University of the Western Cape, Department of Anthropology and Sociology. His main research interests include the ethnography of war, the military and politics, army desertions in postcolonial Africa, and soldiers and the environment. E-mail: gmaringira@gmail.com 
Keywords: Army deserters; military professionalism; politics; war veteran; soldiers; Zimbabwe

\section{Introduction}

In many postcolonial African countries, the military has become embedded with and in politics, either propping up or rebelling against the ruling regimes. This article focuses on the ways in which the Zimbabwe National Army (ZNA) became an armed appendage of the ruling party and how such a practice dictated the ways in which soldiers lived their lives and were promoted in the army barracks. By definition the military is an institution with a neutral code of conduct, where the promotion and demotion of soldiers' ranks is based on institutional professional conduct. In the ZNA, however, such criteria and practices have been openly politicized, based on patron-client relationships between President Robert Mugabe and the army generals. I analyze political speeches by serving army generals who are war veterans in which they lionize the regime in power and denigrate the opposition political party, the Movement for Democratic Change (MDC), led by Morgan Tsvangirai. In analyzing the generals' support for President Mugabe, the article draws on the concept of "military patrimonialism," in which the military backs a ruling regime while opposing political reforms by opposition political parties because it has more to lose from such reforms (Lutterbeck 2013). In their political statements, army generals threaten the opposition party before, during, and after elections. They demote postindependence recruits who are perceived to be sympathetic to opposition aspirations. Thus the entrenching of politics in the army has explicitly categorized soldiers into (aging) "war veterans," those who fought in the liberation struggle and are still in the army, and "postindependence" soldiers who joined up in postindependence Zimbabwe. Following this, the article also draws on Huntington's (1957) understanding of military professionalism as "civilian objective control," which assumes that the military is apolitical and subordinate to civilian political leadership. While the stories of postindependence soldiers who deserted the military and are now living in exile do not provide a complete narrative of the military, their reflections do provide a vantage point from which to understand the ways in which the ZNA remained an armed appendage of the ZANU-PF. They reveal a hierarchy kept in place through the abuse of power by ZNA generals and other war veterans still serving in the ZNA, designed to suppress opposition politics and control the actions of postindependence soldiers in the barracks. The term "war veteran" is used here to refer to guerrilla fighters who fought in the Zimbabwe liberation struggle and were later integrated into the new ZNA in 1980 at Zimbabwe's independence.

Even though soldiers who joined the army in postindependence Zimbabwe have been deployed and have fought in two war zones, the Mozambique war (1986-92) and the Democratic Republic of Congo war 
(1998-2002), they are perceived, especially by the top structure of the army, as a different category of soldiers. In the barracks, and even in public, veteran soldiers accepted such categorization, whereas postindependence soldiers understandably contested these informal categories. This is so because soldiers who are classified as a war veterans receive military and political benefits such as promotion and recognition. Those classified as postindependence soldiers are often denigrated and regarded as "cowards" and "sell-outs" in the military barracks if they do not publicly support President Mugabe. The latter soldiers, whose stories form the basis of this article, are now officially classed as deserters. They speak about their experiences and shed light on the ways in which the military hierarchy has deviated from professional ethics to dictate soldiers' lives in the barracks and determine the promotion and demotion of soldiers. I focus on how this was played out and mediated in the army barracks through favoritism: the promotion of war veterans and demotion of postindependence soldiers. Below, I first reveal the ways in which military professionalism has been understood and contested and how African militaries have been politicized. In their own minds this category of disappointed former soldiers subscribe to Huntington's ideal of what constitutes a professional military corps, dedicated to defending society and not swayed by its own agenda despite the changes in public political structures. It is a mind-set that regards one's personal political choice as private and the soldiery as neutral observers rather than actors, obliged and willing to defend all citizens regardless of politics. They feel the army should be seen in this way by a new civilian command structure, even if its values are very different from those of its predecessor. I then explore how I met these former soldiers in exile in South Africa. I provide background on the ZNA, describing how it was formed and later deprofessionalized through invasive involvement in politics, which led to the desertion of many of my participants and their finding refuge in exile in South Africa. In the last section of the article I discuss the narratives of postindependence soldiers regarding what they considered the unprofessional practice of the army, thereby helping to reveal how they understand professional conduct within the military barracks.

\section{Politicized Armies: Africa and Beyond}

The active involvement of the military in politics is neither unique to Africa nor a new phenomenon in Zimbabwe. Early scholars such as Huntington (1957) argue that if military professionalism is to be achieved, the military has to subordinate itself to civilian politics, a practice that he calls "objective civilian control." Features of military professionalism include integrity, competence, obedience, honor, and trustworthiness (Kohn 2009; Sarkesian \& Conor 2006; Moskos et al. 2000). However, military professionalism is a broad concept, often difficult to define both in theory and practice. For Sarkesian and Conor (2006), military professionalism is characterized by at least two tiers: on the one hand, the relationship between the military and national leadership, and on the other, practices within the military itself. 
This article examines both tiers, especially the ways in which the former affects the latter. Thus, while scholars such as Janowitz (1960) emphasized that the military is a "constabulary force" with an obligation to protect the citizens, Caforio (2007) maintains that the sole client of the military is the state. This is well supported by Barany (2012), who notes that the military is an important institution maintained by states. It follows that the military is torn and often journeys between protecting ordinary citizens and protecting political leadership. Thus Kohn (1997:1) argues that "there exists no set of standards by which to evaluate whether civilian control exists, how well it functions, and what the prognosis is for its continued success." This is quite clear in the Zimbabwean context, where despite military subordination to the civilian political leadership of President Mugabe, military personnel still plunge themselves into politics and regularly ridicule opposition parties. The broad understanding of this continued military involvement in Zimbabwean politics can be framed around "patrimonialism," a Weberian (1978) concept of a system of personal rule in which the leader dispenses benefits to subordinates in return for loyalty and support to stay in political office. This is evidenced by army generals' political statements in defending and supporting Mugabe to perpetually remain in power in return for promotion and other extended and unaccounted benefits. Similarly, in the Middle East Arab military officers have emphasized that politics was too important to be left to civilians, whom they saw as incompetent and corrupt (Rubin 2001).

There are three types of military involvement in politics: the military as "moderators" who support the government behind the scenes; as "guardians" who protect the government but can seize power if or when they feel threatened by civilian politicians; and as "rulers," who are ambitious and want to rule (see Perlmutter 1969; Nordlinger 1977). While the ZNA does not fit in the second or third category, it goes beyond the first category because it has a track record of public support for the current Mugabe regime. Drawing from Goffman's (1961) idea of "total institution," Rubin (2001) asserts that the military as an institution is isolated from the rest of society; hence it regards civilian politicians as untrustworthy. Thus the army regards civilians with hostility and threatens their political will (Bill 1969). In the Middle East, the military is at the center of instituting or thwarting political change (Bill 1969). Such actions reveal the involvement of the military in politics. However, Perlmutter (1969) argues that in fact it is the civilians who turn to the military for political support. Politicians keep senior army officers happy by rewarding them with privileges and incentives. This has also been the situation in Turkey's politics, where incentives are used to keep military officers in tow to protect the civilian government (Tachau \& Heper 1983). Writing before the Arab uprising, Harb (2003:289) contended that a state of mutual accommodation existed, an unspoken agreement between the military and the government: military interests and privileges would be accommodated in exchange for army discipline and loyalty. In Egypt, as long as the military accrues its privileges, it has no public interest in politics (Albrecht \& Bishara 2011). But why is the military involved in politics? This question may seem naïve because, 
as Finer (1962:5) claims, "Instead of asking why the military engage in politics, we ought to surely ask why they ever do otherwise."

Military disengagement from politics, or the withdrawal of the military from a direct role in everyday civilian politics, simply transforms soldiers into interested political actors. It is only in theory that the military can be said to have disengaged from politics. As Harb (2003) observes, even though there have been calls to re-professionalize the military in Egypt, army generals remain connected with politicians. Thus military disengagement from politics is "hardly ever final or complete" (Harb 2003:274). For example, in Uganda, serving army generals and colonels have been appointed as ambassadors, government ministers, or principal directors of selected ministries (Tripp 2010). Former General Aronda Nyakairima was the internal minister (from 2003 to 2013), Lieutenant General Ivan Koreta was an ambassador designate, and Lieutenant General Robert Rusoke was an ambassador to South Sudan (Kasasira 2014). The appointment and integration of the military into civilian government has to do with the military understanding of politics.

In his celebration of military involvement in politics, Bill (1969) adds that because the military is well organized and well disciplined, and has the capacity to use force, it is politically well placed to claim political power in situations where it sees fit. For Barany (2011) there is no institution that matters more to keep the government in power than the military. Harris (1965) suggested that the best way to keep the military loyal to the government was to involve it in politics. Like any other political actor, the military has institutional goals and interests to advance and protect (Barany 2011). In Egypt, with the destruction of other political institutions (where the military had thrived over the years), the military was left as the only institution to maintain political order (Karawan 2011). However, the Egyptian military did not show awareness of the responsibility it had to take on to lead in political governance, and this was clear in its lack of transparency or constitutional amendments to prepare for new democratic elections (Albrecht \& Bishara 2011).

Whether or not military involvement in politics is perceived as politically beneficial, it goes against the grain of the professionalization of the army, which can be traced in several southern African countries, including Zimbabwe, to the work of the British Military Advisory Training Team (BMATT). These officers were tasked with assisting Zimbabwe in combining the guerrilla armies of ZANLA and ZIPRA with the former Rhodesian forces into a cohesive and professional unit, as I explain later. While Huntington (1957) emphasized that professionalization of the military had to do with a complete subordination of the military to civilian authority, such a conceptualization falls short in understanding the Zimbabwean military. In essence, the Zimbabwe military subordinates itself to the civilian government headed by Mugabe, but that does not in any way make it a professional military grouping. In fact, the subordination of the military to the civilian government makes commanders ruthless and interested individual actors who denigrate opposition political parties. 
Professionalizing the military involves the everyday life of soldiers in the barracks, including interaction between officers of different ranks. Thus the ways in which senior officers act and behave toward junior officers have to be understood as professional and ethical. In his definition of professionalism in the military, Perlmutter (1969) notes that this involves the establishment of specialized military training, building modern military structures, and maintaining a group of well-trained, unified soldiers who have made the military their career. While this author expands our understanding of what it means to have a professional army, it is still elementary in the sense that it emphasizes the establishment of institutional structures rather than the everyday moral, social, and political conduct of soldiers, the rank-and-file in the army barracks, or even the needs of war. Efficient training does not preclude an active interest in politics (see Kamrava 2000). Below, I reveal the ways in which the former soldiers were contacted and interviewed in South Africa.

\section{Contacting Former Soldiers in Exile}

In 2009, quite by accident, I encountered Alpha Romeo (a pseudonym) in Johannesburg, South Africa. He was a former soldier; we had trained together in the military. We were happy to meet away from the barracks and converse about our time at war and in the barracks. Because Alpha Romeo had arrived in Johannesburg five years before me, he was already part of a network of former soldiers. He gave me contact details of former soldiers with whom we had trained, gone to war, and worked in the barracks. I had known the majority of these former soldiers in the ZNA. They range in age between thirty and forty-five. Throughout this research I relied on cell phone contacts, in which former soldiers phoned me and would share the contact information for others. I later contacted these men and organized an informal meeting. At our meeting we caught up and discussed the past rather than focusing on the present. I became more interested in doing research among these former soldiers. I shared this idea, and they all agreed, provided that there was anonymity. In this paper I use military code names such Alpha Romeo, Whisky Papa, India Sierra, Charlie Bravo, and so forth. I had not envisaged developing an interest in military research, but found it fascinating to study my former comrades-in-arms away from the barracks. Given that I was also a former soldier, my participants found it amusing for me to question them about barracks experiences and the life that we had lived together. I had knowledge of what I was asking about, so there was no need for them to talk about it in greater detail. After analyzing their good-humored resistance, I employed a life-history approach, asking them just to share with me their life stories, including the time before they joined the military and their lives as soldiers in combat. They agreed to this. What fascinated me was that they did not dwell on their lives before they joined the military, preferring to plunge straight into their lives in wartime and in the barracks; this comprised the bulk of their stories. 
Their narratives about their experiences evoked my own military past, and I reminisced on my own combat story as a way of extracting the best material from each situation. Even after a day of doing fieldwork with these ex-soldiers, their stories kept coming back to mind. However, this must not be perceived as a "traumatic" experience; rather, for me it is a normal connection with combat life. In certain moments the realization that men who had undergone military training and war found themselves in exile because of what they considered the ZNA's unprofessional conduct and practices evoked a strong emotional response. It was a time to think deeply about what these stories meant to these anonymous former soldiers. Some scholars view reflexivity and subjectivity as a kind of an inside knowledge of and about research that might inject some emotional bias. Drawing from Higate and Cameron (2006) on researching the military, I found that when dealing with former soldiers I stood to gain much in terms of accessing and understanding their lives in war and peace.

I use life histories to allow these former soldiers to speak in detail about their past as well as their present. Thus this article is not only about their past barrack experiences, but also the ways in which they reflect on them. In doing such life histories I visited these men in their places of residence. Because of the perception of Zimbabwean soldiers as perpetrators of political violence against civilians, the ex-soldiers I interviewed did not want to be identified by other migrants in South Africa as men who had once worked as soldiers. During one of my visits to their places of residence for interviews, a former soldier asked me not to talk about his military past or tell others that he had been a soldier because he did not want to be associated with perpetrators of violence. Between 2011 and 2012 I collected fifty-eight life histories and held two focus group discussions, recording them all with the men's consent. No formal criteria were used to choose those who could be part of group discussions. Instead, when the former soldiers came together in groups of five or six for social talks, I would use those opportunities to talk about their lives in the military. Because they have strong networks drawn from their military past, it would have been difficult if not impossible for a person with no military background to gain access to them, given their fear of possible retribution. I understand that in some cases researchers with no military background do succeed in interviewing former soldiers, but this would not have been feasible with my participants. Since they were regarded as army deserters, they were not willing to talk to "outsiders" for fear of being spied on by Mugabe's intelligence officers, who were and are believed to be present in South Africa.

\section{The ZNA and Politics}

The Zimbabwe National Army was formed at independence in 1980 through the integration of rival political factions: two former guerrilla armed forces and the Rhodesian Security Forces (white and black soldiers). The two guerrilla forces were the Zimbabwe African National Liberation Army (ZANLA), an armed wing of the Zimbabwe African National Union-Patriotic Front 
(ZANU-PF) led by Robert Mugabe, and the Zimbabwe People's Revolutionary Army (ZIPRA), the armed wing of the Zimbabwe African People's Union (ZAPU), led by Joshua Nkomo (see Jackson 2011; White 2007; Young 1997). Alexander (1998) reported that the two guerrilla formations were divided along ethnic lines, with ZANLA dominated by the Shona and ZIPRA by the Ndebele; hence their recruitment was also mainly in Mashonaland and Matabeleland provinces, respectively. The integration of guerrilla armed formations in the new ZNA was supervised by the BMATT from 1980 to 2001 (see Kriger 2003; Young 1997; Alao 1995). The idea was to ensure that the newly formed army adhered to certain professional benchmarks, guidelines, and codes of conduct and to ensure that the ZNA was technically up to international standards, as well as educated in military ethics (Alao 1995; Tendi 2013).

Despite the BMATT presence, there were still clear ethnic divisions and lines of allegiance in the new army (White 2007). This was evident in 1983 when the 5th Brigade, trained by the North Koreans and largely dominated by ZANLA forces, was deployed in Matabeleland province to destroy arms caches and suppress an alleged uprising of ZIPRA dissidents (Jackson 2011; Alao 2012; Alexander 1998). The operation was dubbed "Gukurahundi," which translates as "the first rain which washes away the chaff" (White 2007; Jackson 2011). In this case the Ndebele people were seen as the chaff to be decimated. In her observations about the new ZNA, Alexander (1998) notes that the former ZIPRA soldiers were victimized by ZANLA forces and this led to their desertion. When ZAPU leaders such as Lookout Masuku and Dumiso Dabengwa were arrested but found not guilty, they were detained indefinitely without legal trial. Masuku died of meningitis after his release from prison but there was some suspicion about the cause of his death. The desertion of former ZIPRA soldiers was compounded by the forced exile of Joshua Nkomo, their leader. Those who deserted were labeled dissidents. The deployed 5th Brigade "hunted down dissidents" and in the process killed more than twenty thousand civilians (Alexander 1998). As a way of halting this form of military violence, in 1986 the unity accord was signed between Mugabe and Nkomo, with the latter being appointed second vice president of the country.

As part of strengthening the new army, the ZNA embarked in 1986 on a mass drive to recruit young men and women who had not been part of the liberation struggle. This mass recruitment formed the 6 th Brigade. The idea was to regenerate the army by introducing "new blood" and to build a stronger and professional army disconnected from politics (see Maringira 2015; Young 1997). A conversation with my participants revealed that during the initial recruiting drive up to the year 2002, the army aimed to recruit youths with at least five ordinary-level (O-level) passes for general duty soldiers and six points advanced-level (A-level) passes for officer cadets. In order to shore up military support for Mugabe, however, from early 2000 the army targeted people from poorer families, even those with only a grade seven qualification, provided they were drawn from ZANU-PF youth wings. In essence, the early postindependence violence in Matabeleland testifies that 
the ZNA has never been professional in its code of conduct (Masunungure 2011). Thus scholars such as Alao (2012) contend that Zimbabwean politics and the military have always been intertwined.

This deep relationship was evidenced by army generals after 2000 when they publicly declared their allegiance to the ZANU-PF (see Chitiyo 2009; Ndlovu-Gatsheni 2009; Tendi 2013). This was so because the MDC had also presented major changes it would implement in the military once it was voted into power. For the generals, this was a threat to their power base, the ZANU-PF. Hence, the army generals defied the Constitution of Zimbabwe, section 208 (2), and in particular the Zimbabwe Defence Act, chapter 11:02, which states that the armed forces are supposed to be apolitical. In 2002 the late General Zvinavashe openly stated that he would only salute those who had fought in the liberation struggle (see Tendi 2013). The liberation struggle narrative was in itself a metaphor to resist any other presidential candidate with no liberation history, given that Mugabe had fought in the liberation struggle. This was a statement against Morgan Tsvangirai, leader of the opposition party the MDC, who had never fought in the liberation struggle. This attitude was extended to other uniformed forces, such as the Prisons Commissioner, Major General Paradzai Zimondi, and Police Commissioner General Augustine Chihuri (see McGreal 2008). Their outspoken allegiance to the ZANU-PF meant that soldiers who did not conform were subsequently punishedinitially, mainly through demotion. This political mantra was constantly emphasized among soldiers in all ZNA battalions. In 2003 the Zimbabwe Military Intelligence Corps director, Morgan Mzilikazi, then a lieutenant colonel and since promoted to a rank of brigadier general, and Fidelis Mhonda, then director of the military police and now a brigadier general, visited all battalions, addressing soldiers on the implications of voting for the MDC. In 2007 the Zimbabwe Defence Forces commander, General Constantine Chiwenga, visited all the brigades, emphasizing that the position of the military was to support President Mugabe. Yankee Romeo, a former soldier, who was in one of Chiwenga's parades, notes that "as soldiers, we were made to understand that President Robert Mugabe is always right and the MDC is a sell-out." However, the visit by senior army officers to all ZNA battalions with a political message to prop up Mugabe is a clear testimony that the ZANU-PF and Mugabe had to work quite hard to convince soldiers who joined the military in postindependence Zimbabwe. This is evidenced by Tango Delta, who notes that "when I was trained in 1986 by Colonel Lionel Dyck [a former Rhodesian white officer integrated into the ZNA], politics was never part of our field craft lessons." Thus, because of the growing popularity of the MDC, the army became the last lifeline of the ZANU-PF. Whisky Papa contends that "since I joined the military [in] 1986, I have never seen army generals talking politics on parade, more so visiting all battalions with a political message to support ZANU-PF." Such revelations provide a vantage point for us to understand how the MDC emerged as a strong political contender, an issue which prompted the military generals to be active politicians in combat uniform. Quoted in the state daily newspaper, The Herald, Chiwenga emphasized that: 
I would not hesitate to go on record again on behalf of the Zimbabwe Defence Forces, to disclose that we would not welcome any change of government that carries the label "Made in London", and whose sole aim is to defeat the gains of the liberation struggle. (Independent Foreign Service 2009)

The general's misguided assumption was that opposition politics in Zimbabwe was founded in Britain, hence his political efforts to block the will of the people through military threats. Such an explicit political threat by the Zimbabwe Defence Forces general commander testified that Mugabe was strongly backed by the army; it was not a secret anymore. This is what Rupiya (2011) refers to as the "politicization of the military," in which the military became actors in Zimbabwean politics. Ranger (2004a) refers to this as "patriotic history": dividing a nation into black and white, patriots and "sell-outs." Importantly, it perceived opposition political parties as "made in London," which was a tool to threaten civilians and junior soldiers who did not openly support Mugabe. As noted by Whisky Papa, "it was quite difficult for us as soldiers, in our social conversations in the barracks-either you support President Mugabe or you denigrate the MDC." Such an idea of shifting junior soldiers' social talks into political conversations reveals that the military barracks became political spaces meant to serve the dwindling regime of Mugabe.

But why is it that the Zimbabwe army generals were so deeply involved in politics at a time when the country was in dire economic and political crisis? There are at least three relevant observations. The opposition political party, the MDC, was advocating security sector reform-in other words, the military was supposed to leave politics to civilians. Army generals benefited from the contested land reform program, through which they were allocated large tracts of productive land violently seized from white farmers in Zimbabwe, and they feared that once the opposition came into power they would lose their land. Army generals' conditions of service were also strongly tied to their loyalty to Mugabe and public participation in politics, as Mike Tango notes: "Generals were each allocated at least three cars, one luxury and two for their farms. In addition, generals had access to unaccounted fuel in the barracks, some which was used on their farms." This reveals to us that part of the reason that President Mugabe rewarded military generals was that it was a kind of appeasement to a potential threat. In summary, the government under the ZANU-PF and President Mugabe provided for army generals' personal and family lives. Hence they were reluctant to support any political processes that would lead to a change in government. This is a typical patron-client arrangement between the political system and the military (Murphy 2003; Weingrod 1968; Ikpe 2000). As Lutterbeck (2013:32) argues, "the reason why a military or security apparatus based on patrimonialism is more likely to oppose political reforms and regime change is that it has more to lose from such reforms." In this case, Mugabe emerges as a patron and the army generals as clients, cooperating in mutually beneficial practices as the former sought protection from the latter. This also serves to explain why serving army generals were continuously on a political rampage, 
engaging in unprofessional conduct by threatening the opposition political party, the MDC led by former prime minister Morgan Tsvangirai.

In order to show their political attachment and affiliation to President Mugabe, Major General Douglas Nyikayaramba (promoted in 2012) presented Tsvangirai as a security threat. He underlined that

\begin{abstract}
Morgan Tsvangirai doesn't pose a political threat in any way in Zimbabwe, but is a major security threat. He takes instructions from foreigners who seek to effect illegal regime change in Zimbabwe. Daydreamers who want to reverse the gains of our liberation struggle . . can go to hell. . . They will never rule this country. (Voice of America 2011)
\end{abstract}

These sentiments were more political than military, as the speech targeted the opposition political leader. But whether army generals' threats to the MDC were a result of the internal dynamics in Zimbabwe or external influences remains a moot question. In his response to Zimbabwe army generals' political statements, Tendi (2013) presents an illuminating argument. He argues that such political statements by Zimbabwe army generals are a response to external political influence and the involvement of Western countries, in particular the U.S., in Zimbabwean politics since 2000. The generals' political statements were made in response to Western media reports and representations of Mugabe, who was universally portrayed as intolerant. From 2000, the E.U. and U.S. governments had imposed sanctions on Mugabe and his cronies in the ZANU-PF, including some notable senior military officers. Moreover, the BMATT was withdrawn by Britain and efforts to professionalize the ZNA were abandoned. All these issues reportedly angered the generals and fed into their consequent harsh responses to opposition politics in Zimbabwe.

While Tendi's arguments seem correct, I also argue that internal dynamics, especially in the Zimbabwe military, add to our understanding of why the generals behaved the way they did in constantly debasing the MDC. The former soldiers' stories, like that of Sierra Romeo, show that "generals and other war veterans in the army were fighting for their own career benefits like promotion." Tango Alpha Tango notes that "it was well known that from the rank of lieutenant colonel to general, they are political ranks." Thus the majority of generals who openly threatened Morgan Tsvangirai were promoted. For example, Major General Nyikayaramba, then brigadier general and commander of the 3 Brigade, made inflammatory statements; within months he was promoted to the rank of major general and transferred to army headquarters in Harare. Apparently, public threats to the opposition political party were a resource for promotion in the army. Similarly, in 2008 Major General Chedondo ordered soldiers to vote for the ZANU-PF. In his speech at a parade he publicly said:

We cannot be seen supporting a political party that is going against the ideals of a nation. ZANU-PF came about as a result of a liberation struggle, 
which saw many of the country's sons and daughters losing their lives. As soldiers we must support ideologies that we subscribe to, I for one will not be apologetic for supporting ZANU (PF) because I was part of the liberation struggle. (Zimbabwe Mail)

Soldiers are not apolitical ... we have signed an agreement to protect the ruling party's principles of defending the revolution. If you have another thought, then you should remove your uniform. The constitution says the country should be protected. . . . We shall therefore stand by our commander-in-chief, President Mugabe (Sapa-dpa 2008).

In this speech Major General Chedondo used the history of the liberation struggle to generate support for Mugabe's regime. This is what Ranger (2004b) refers as "Mugabe-ism," the celebration of Mugabe as the alpha and omega of Zimbabwean politics (see also Tendi 2008). In this case, it is soldiers in uniform who are supposed to vote for President Mugabe. The ZNA general's statement that soldiers who opposed President Mugabe "should remove their uniform" was not only for public consumption in the media-in practice, soldiers were made to understand that the ZANU-PF dictated the ways in which the military had to function. The ways in which the constitution was incorrectly applied simply meant that the army was intolerant of the opposition political party. In fact the constitution states that the military shall protect the (entire) nation, not the ZANU-PF as a political party. The constitution does not in any way state that the ZANU-PF will be protected from other political competitors, and ZANU-PF does not equate to "the nation." For army generals, however, the ZANU-PF comprised the "nation" that had to be protected against any would-be political opponent trying to win votes in Zimbabwe. What should be noted is that the army generals were not alone in this clientelism. In a speech to a group of war veterans, President Mugabe confirmed the political "marriage" with the military and thanked them for supporting his regime. He noted, "We are grateful to war veterans and the military for playing their role. We extended their contracts when they had expired so that they could assist us in fighting the opposition; we came out victorious" (Mambo 2016). It follows that while President Mugabe is defended by the military, army generals' positions and tenure are protected by him in return. Thus the confirmation by Mugabe revealed a deeply seated historical relationship between the army and the ZANU-PF (see Alao 2012; Chung 2006; Mazarire 2011; Mhanda 2011). The distinction between the ZANU-PF and the ZNA is completely blurred. The ZANU-PF overshadowed all structures of governance and all national institutions. The patron-client relation still favors and prioritizes army generals, viewed as the vanguard of the army and of the nation, with Mugabe as the driving force. The aspirations of more recent recruits (postindependence soldiers) to serve their country were directly affected by the ZANU-PF infusion of national politics to control life in the barracks. For these young soldiers, what was supposed to be a nonpartisan and professional calling had become part of a political party 
construct in which soldiers were compelled to vote for the ZANU-PF. The army had become a ZANU-PF tool embedded in politics and directed by politicians. Soldiers were coerced to openly support and proclaim ZANU-PF as their employer.

\section{Soldiers and Politics in Army Barracks}

While civilians often perceive soldiers as a cohesive unit because they march and parade together, there are profound differences based on character and a different understanding of politics. The narratives of my participants reveal that soldiers in the ZNA barracks were and continue to be divided between two categories: liberation veterans and the soldiers who joined the army in postindependence Zimbabwe, who mainly hoped to pursue a professional military career. The majority of my participants deserted the army because of political persecution such as being targeted on the parade square and being punished and tormented in the barracks by veteran soldiers. As noted by Alpha Lima, "if you are late on parade square, the regimental sergeant major (RSM) will say you were attending an MDC rally." In the military barracks soldiers were not allowed to read privately owned newspapers such as the Daily News and the Standard, listen to Voice of America broadcasts, or tune in to $\mathrm{CNN}, \mathrm{BBC}$, or $\mathrm{Al}$ Jazeera because they were viewed as the mouthpieces of the MDC. In his narrative, Sierra Mike says, "It was well known that tuning to CNN or BBC was regarded as disobedience to lawful command, which was in itself a chargeable offense." But to say these army deserters all supported the MDC would be a misrepresentation. Rather, they would say that they supported neither the MDC nor the ZANU-PFthey were merely trying to be professional soldiers. The fact that they did not publicly support the ZANU-PF or ridicule the MDC as their commanders did was wrongly perceived as support for the opposition party. As revealed by Charlie Mike, "I was never trained in politics, but the gun." What these former soldiers considered to be professional training depended on their knowledge of weaponry, not politics. Their understanding of military professionalism is similar to that of British serving and former soldiers as described by Woodward and Jenkings (2011): defined around a military identity, which entails expertise and knowledge of surveillance, map reading, and so forth. For my participants, politics was literally a foreign and unknown practice. For Alpha Bravo,

There were two different armies in the Zimbabwe National Army. I remember the brigadier telling the brigade sergeant major that you must beat all young soldiers so that they can be disciplined. You must treat them roughly. I remember him emphasizing that only war veterans must be respected but these other ones who are not war veterans-deal with them.

The distinction between veteran soldiers and junior soldiers was made clear by senior officers in the military, such as the brigadier. The hierarchy 
of command was clearly used to "discipline" young soldiers, who were subjected to beatings. While veteran soldiers were shown respect in the army barracks, soldiers who joined the army in postindependence Zimbabwe were made to suffer. The whole idea of "dealing with them" simply translated into the abuse of junior soldiers-making them realize their precarious position as the "other" in uniform. They were targeted for exclusion from what any professional soldier should enjoy in uniform: professional conduct. This was also manifested through the politics of promotion in the army barracks. Whisky Papa emphasized that:

There was favoritism, with war veterans being treated like a grade A-Army and the rest of us being Grade B, C, or D. The military must be cohesive; it must have a single identity. It must operate in a professional manner whereby abilities are the only things that should be considered in a person's promotion. It should not be about duration in your military.

In a professional army promotions are determined by expertise, ability, and education (see Perlmutter 1969). They are based on merit (Lutterbeck 2013). But in situations where the military is politicized, military patrimonialism overrules the professional code of conduct (see Murphy 2003). The concept of military patrimonialism reveals the ways in which political leaders redistribute resources to individuals and not to the institution in return for loyalty and political support (Pitcher et al. 2009; Lutterbeck 2013; Crouch 1979). In this case distribution of such resources is driven by "political favouritism and cronyism" (Lutterbeck 2013:32). In such a context, the promotion of soldiers is based on patronage. But this does not mean that those who practice this kind of patronage are not aware of professional conduct; rather, clientelism becomes a template for promotion to advance certain political agendas. As Lutterbeck (2013) notes, patrimonialism is individual, not institutional, but it becomes institutional when individuals entrench their thoughts, actions, and experiences in institutional practices. This reveals to us that military promotions in a politically volatile situation are wholly subjective. Thus, military patrimonialism is not just a tactic or strategy employed at certain political moments; it is an "embodied" practice (see Bourdieu 1990) in military barracks, which leads men in uniform to act in specific ways. For Whisky Papa this was unprofessional, because an army should promote individual soldiers based on merit:

Look at it, it's not about the type of people. If you have abilities you are supposed to be promoted according to your abilities because this is a national institution. This is about national security. It's not about allegiances. It is not about the period you have served in the army. When you join the army you join a professional organization in which your abilities are the reason for the promotion process, but that was no longer happening. We were now seeing two armies: there was the lesser army and the main army. Yet we are not saying that all war veterans were bad-no, no, that's not the case. There are a lot of good war veterans, very good guys but 
they ended up also being made to believe that they are more superior but that was never the case.

The feelings of frustration, anger, and "othering" in the ZNA were echoed by many soldiers. They questioned and criticized the army for having no uniform standard for promotion. It was clearly stated in the ZNA promotion memoranda that to be promoted from the rank of corporal to sergeant one had to pass military courses such as junior tactics and squad drill; to be promoted from the rank of sergeant to staff sergeant a senior tactics course had to be passed. To become a warrant officer class 2 , the successful completion of a ceremonial drill course was a prerequisite. Such promotion standards were not followed and in reality ZANU-PF politics took the lead in determining promotion. War veterans were consistently promoted without having to complete and pass the necessary military courses. Tango Oscar, who was with the mechanized brigade, noted that

I had all the military courses, squad drills course, junior tactics, instructors course, ceremonial drill, and other cadre courses, but my promotion to sergeant was stopped; my commander said there are many war veterans waiting for this promotion.

When the army became deprofessionalized, professional and known ways of promoting soldiers were negated. At one time I worked in the battalion as a clerk, and one of my own observations was that by 2010 the majority of the war veterans were already in their fifties. In reality this meant that physically they were no longer able to endure the rigors of tactical military courses. Such courses were physically demanding, and few veterans were up to the task. I remember some of the veterans in the barracks saying "takura hatichazvigoni, zvakuda imi vafana vechidiki" (we are too old now, we can't do anything now, and it is now for you the younger generation). Even though they would say that, they were still demanding and waiting for their next promotion. They wanted to command, although they could no longer "work." Another reason that war veterans could no longer attend military courses was that all tactics courses in the ZNA were conducted in English and the majority of veterans were largely unable to use English or write it at length. This was different from soldiers who joined the army in postindependence Zimbabwe, many of whom had done their ordinary level including English as a subject. A few had done advanced-level studies (an entry qualification to university studies). In all tactical military courses, at the end of every week (for six months), soldiers had to take a test. If a soldier failed three tests, he or she was returned to his or her unit. This was popularly known as RTU (Returned to Unit). Soldiers who returned to their units after failing a military course were charged under the Defence Act, chapter 11:02, for "malingering," meaning that a soldier was not able to perform the duty assigned to him by a superior. In order to circumvent RTUs and avoid being charged, army veterans covered each other's backs, for example by not sending veterans 
to military courses that would require them to take tests in Englishbecause they almost always failed and could be charged as a result. It was considered embarrassing for battalion members to see a war veteran carrying his trunk back to the barracks. Soldiers who joined the military after independence would gossip about the veteran's return to the barracks. Within junior soldiers' cohorts, they used to say, "so he thought English was easy, even in the military."

When I was in the army in 2002, all war veterans were given so-called oneups-automatic promotion to the next rank-as a way of keeping veterans in the army. When veteran soldiers were promoted, this was done with only a signal sent from headquarters. In usual circumstances, the soldier's military profile confirms that the promotion of soldiers was procedural, following recommendations from the battalion and brigade for army headquarters or careers approval. This nonprocedural promotion was political and unprofessional, affecting the lives of junior soldiers in the barracks.

Promotion of all veterans was in a way made to propagate the "preaching" of the ZANU-PF political mantra in the barracks. Civilian politicians were at the forefront in directing and dictating how the military acted and behaved in public. This created distortions of what a professional army should be, with promotion based on political affiliation rather than ability.

Although in the army, as elsewhere, promotion is a symbol of success and competence, in the ZNA promotion had become a signifier of political fidelity to the ZANU-PF regime. Political loyalty became the key determinant of promotions. For Dandeker et al. (2006:162), the "definition of a veteran provides the context within which the government responds to the needs of veterans." This meant that loyalty and patriotism were conceptualized in terms of history and allegiance to the ZANU-PF. It was not about what a soldier could do for the army, but how he (or she) had contributed to ZANU-PF victory, and the party's ability to stay in power. Even though the professional assignment of the army is to provide national security, the ZNA stood out as a political actor, mainly as the protector of the political party in power. For the ZANU-PF, the idea was to deal with the current political challenges in- and outside the army by utilizing the army itself (see Chitiyo 2009; Tendi 2013). Liberation struggle veterans were promoted to maintain the ZANU-PF veterans' presence and influence in the army. While many of the war veterans were not able to read or write, their "legitimacy" for promotion was substantiated by their participation in the past liberation struggle and the current propping-up of President Mugabe in power. Promotion for soldiers who joined the army in postindependence Zimbabwe was perceived as endorsing the MDC. By contrast, the advancement of war veterans was seen as victory for Mugabe and the ZANU-PF. Reflecting on how promotion was done, Bravo Charlie reiterated that

Yeah there were rampant promotions because younger soldiers were now becoming corporals, sergeants, deciding all those things. The other guys [war veterans] were remaining at the bottom and then they said, no, we fought for 
this country, we need promotion. You could see that commanders said to themselves, for us to be able to retain this army let us take these uneducated men, let us take these "extra loyal" people who give the army a political standard and make them commanders of these "other ones" who are professionals so that we maintain a certain Hitler doctrine [laughing], that was now treatment of the army. So the end result was that the promotion system became distorted. The morale went down because of this.

Even though junior soldiers were marginalized in the military promotion system, their narratives display knowledge of a professional army. In a way their narratives are a counter to unprofessionalism. While the ZANU-PF had to all intents imposed its political practices in the army barracks, junior soldiers stood out as another category of soldiers, men who stuck to what they believed in-namely, professionalism. The ways in which war veterans in the army departed from competency and adhered to a partisan style of promotion had social and military implications, such as contributing to low morale. In the military, morale is a linchpin in keeping soldiers going, whether in war or in the barracks. It brings hope even in times of crisis. In military life, morale may be understood in two ways. It primarily reflects the cohesion of soldiers within the unit or barracks (Ulio 1941). An army that cares for its soldiers can be said to have high morale. Low morale shatters the occupation of a soldier. It depletes the soldierly spirit: the desire to protect the nation and execute combat duties as expected by the state in the face of possible death. Thus morale is an "inner spark." Once a soldier is demoralized, everyday routines in the barracks are affected. Like good morale, a lack of morale is seemingly contagious. When competent soldiers are promoted, the rank and file are reassured that they are in good, capable hands. It also gives them the hope that they have a chance be promoted in the future. They feel appreciated.

While promotion strengthens the morale of soldiers, demotion (being stripped of a rank) brings humiliation (and pain) in the army barracks. In the ZNA, demotion was a political technique of exercising power meant to intimidate soldiers and make them subservient to the ZANU-PF. Charlie Mike was demoted and stripped of his rank because he was suspected of being an MDC supporter. He described his ordeal when the brigadier general punished him.

Actually, you know these political commanders, when they saw us, they saw a small soldier, a boy soldier, like a young soldier; they don't treat you as a soldier, but as an MDC soldier. So when you go for the orders, the superior orders, they see politics in you, so instead of him [the brigadier] giving you a fair trial, he puts you on the side of the opposition political party. Even if you are supposed to get a fair sentence they give you a harsh sentence because of that. You see that is what happened to me. When I went for his orders, when he saw me, you know, he saw an MDC soldier, so when I went before him he actually gave me a harsh sentence. He demoted me to a rank 
of a private. I was a corporal and he sentenced me to twenty-one days in Detention Barracks [army prison where soldiers are subjected to harsh punishment].

The excerpt above reveals that the harsh sentence received by Charlie Mike for a minor military offense was the result of his being suspected of being an MDC supporter, although there was no evidence that he supported the MDC. But what is evident in his narrative is that when the military became politicized, military orders or courts became spaces for settling political scores. They ceased to carry out professional conduct of orders and instead introduced purging practices in the barracks, which had become sites for "correcting" junior soldiers and whipping them into what veteran soldiers believed. But military discipline and punishment also revealed how politics influenced professional institutional practices in the army and the ways it damaged its capacity to function as a unified force (Rubin 2001). Charlie Mike used phrases such as "boy soldiers" or "MDC soldiers" to distinguish himself from the brigadier. If MDC soldiers existed in the barracks, such a distinction simply invites us to think also of "ZANU-PF soldiers" in the army barracks. It follows that the way in which a soldier is understood depends on one's war history. If one fell outside the ZANU-PF's liberation history, then he was perceived as an MDC soldier and easily demoted-especially if war veterans regarded him as politically disloyal.

\section{Conclusion}

This article has revealed the ways in which the Zimbabwe National Army has become and remained politicized in- and outside the army barracks, deviating from the professional conduct expected of the military. While in the Zimbabwean context the military is under civilian rule and government leadership, this does not mean army generals are professional soldiers. Thus military professionalism is not only about civilian domination of the military, but also has to do with the daily life of soldiers in the barracks, the ways in which they are promoted and demoted, perceived and understood by the commanding hierarchy. The politicization of the military affects cohesion between senior and lower-rank soldiers. When the military supports the regime in power, military interests are safeguarded in return. Importantly, the article has argued that rather than assuming that it was a given for all soldiers to support the ZANU-PF and President Mugabe, the ZANU-PF had to work quite hard to convince junior soldiers to support it. This was made possible through successive generals' visits to battalions and public speeches in which they threatened the MDC. The article has revealed to us that, as evidenced by early postindependence military involvement in violence, the Zimbabwean military has never been professional, and this has been perpetuated during the post-2000 political and economic crisis when the MDC became a political threat to Mugabe and the ZANU-PF. The fact that the army deserters whose narratives are presented in this paper reveal 
contentious relationships with their commanders indicates that this might not be a complete narrative of the practices within the ZNA. However, their narratives provide a vantage point from which we can understand ways in which the ZNA has remained political, in part for its own benefit in a crisisridden country.

\section{References}

Alao, Abiodun. 1995. "The Metamorphosis of the 'Unorthodox': The Integration and Early Development of the Zimbabwe National Army." In Soldiers in Zimbabwe's Liberation War, edited by Ngwabi Bhebe and Terence Ranger, 104-17. London: James Currey.

- 2012. Mugabe and the Politics of Security in Zimbabwe. London: McGill-Queens University Press.

Albrecht, Holger, and Dina Bishara. 2011. "Back on Horseback: The Military and Political Transformation in Egypt.” Middle East Law E Governance 3: 13-23.

Alexander, Jocelyn. 1998. "Dissident Perspectives on Zimbabwe's Post-independence War, Africa." Journal of the International Africa Institute 68 (2): 151-82.

Barany, Zoltan. 2011. "Comparing the Arab Revolts: The Role of the Military." Journal of Democracy 22 (4): 28-39.

- 2012. The Soldier and the Changing State: Building Democratic Armies in Africa, Asia, Europe, and the Americas. Princeton, N.J.: Princeton University Press.

Bill, James. 1969. "The Military and Modernisation in the Middle East." Comparative Politics 2 (1): 41-62.

Bourdieu, Pierre. 1990. The Logic of Practice. Stanford, Calif.: Stanford University Press.

Caforio, Giuseppe. 2007. "Introduction: The Interdisciplinary and Cross-National Character of Social Studies on the Military-The Need for Such an Approach." In Social Sciences and the Military: An Interdisciplinary Overview, edited by G. Caforio, 1-20. London: Routledge.

Chitiyo, Knox. 2009. The Case for Security Sector Reform in Zimbabwe. London: Royal United Services Institute.

Chung, Fay. 2006. Re-living the Second Chimurenga: Memories from the Liberation Struggle in Zimbabwe. Stockholm: Nordic African Institute.

Crouch, Harold. 1979. "Patrimonialism and Military Rule in Indonesia." World Politics 31 (4): 571-87.

Dandeker, Christopher, et al. 2006. "What's in a Name? Defining and Caring for 'Veterans': The United Kingdom in International Perspective." Armed Forces $\mathcal{E}^{\circ}$ Society 32 (2): 161-77.

Finer, Samuel. 1962. The Man on Horseback: The Role of the Military in Politics. London: Pall Mall Press.

Goffman, Erving. 1961. Asylums. London: Penguin.

Harb, Imad. 2003. "The Egyptian Military in Politics: Disengagement or Accommodation?" Middle East Journal 57 (2): 269-90.

Harris, George. 1965. "The Role of the Military in Turkish Politics." Middle East Journal 19 (1): 54-66.

Higate, Paul, and Ailsa Cameron. 2006. "Reflexivity and Researching the Military." Armed Forces Ev Society 32 (2): 219-33.

Huntington, Samuel. 1957. The Soldier and the State: The Theory and Politics of CivilMilitary Relations. Cambridge, Mass.: Harvard University Press. 
Ikpe, Ukana. 2000. "Patrimonalism and Military Regimes in Nigeria." African Journal of Political Science 5 (1): 146-62.

Independent Foreign Service. 2009. "Zimbabwe Army Chief 'Won't Allow Change of Power." www.newzimbabwe.com.

Jackson, Paul. 2011. "The Civil War Roots of Military Domination in Zimbabwe: The Integration Process Following the Rhodesian War and the Road to ZANLA Dominance." Civil Wars 13 (4): 371-95.

Janowitz, Morris. 1960. The Professional Soldier: A Social and Political Portrait. New York: Free Press.

Kamrava, Mehran. 2000. "Military Professionalization and Civil-Military Relations in the Middle East.” Political Science Quarterly 115 (1): 67-92.

Karawan, Ibrahim. 2011. "Politics and the Army in Egypt." Survival 52 (2): 43-50.

Kasasira, Risdel. 2014. "Who Is Who? List of UPDF Top Brass and What They Do." Daily Monitor, Kampala, November 27. www.monitor.co.ug.

Kohn, Richard. 1997. "How Democracies Control the Military." Journal of Democracy 8 (4): 140-53.

- 2009. "Tarnished Brass: Is the U.S. Military Profession in Decline?" World Affairs 171 (4): 73-83.

Kriger, Norma. 2003. "Zimbabwe: Political Constructions of War Veterans.” Review of African Political Economy 30 (96): 323-28.

Lutterbeck, Derek. 2013. "Arab Uprisings, Armed Forces, and Civil-Military Relations.” Armed Forces E Society 39 (1): 28-52.

Mambo, Elias. 2016. "Mugabe Remarks Expose Military." April 15. www.theindependent. co.zw.

Masunungure, Eldred. 2011. "Zimbabwe's Militarized, Electoral Authoritarianism.” Journal of International Affairs 65 (1): 47-64.

Maringira, Godfrey. 2015. "When the War De-Professionalises Soldiers: Wartime Stories in Exile." Journal of Southern African Studies 41 (6): 1315-29.

Mazarire, Gerald. 2011. "Discipline and Punishment in ZANLA: 1964-1979.” Journal of Southern African Studies 37 (3): 571-91.

McGreal, Chris. 2008. “'We Will Not Let Mugabe Be Beaten,' Police and Army Chiefs Warn." The Guardian, March 15. www.theguardian.com.

Mhanda, Wilfred. 2011. Dzino: Memories of a Freedom Fighter. Harare: Weaver Press.

Moskos, Charles C., John Allen Williams, and David R. Segal, eds. 2000. The Postmodern Military: Armed Forces after the Cold War. New York: Oxford University Press.

Murphy, William. 2003. "Military Patrimonalism and Child Soldier Clientalism in the Liberian and Sierra Leonean Civil Wars.” African Studies Review 46 (2): 61-87.

Ndlovu-Gatsheni, Sabelo. 2009. "Making Sense of Mugabeism in Local and Global Politics: 'So Blair, Keep Your England and Let Me Keep My Zimbabwe.'” Third World Quarterly 30 (6): 1139-58.

Nordlinger, Eric. 1977. Soldiers in Politics: Military Coups and Governments. Englewood Cliffs, N.J: Prentice-Hall.

Perlmutter, Amos. 1969. "The Praetorian State and the Praetorian Army: Toward a Taxonomy of Civil-Military Relations in Developing Polities." Comparative Politics 1 (3): 382-404.

Pitcher, Anne, Mary Moran, and Michael Johnston. 2009. "Rethinking Patrimonialism and Neopatrimonialism in Africa." African Studies Review 52 (1): 125-56.

Ranger, Terence. 2004a. "Nationalist Historiography, Patriotic History and the History of the Nation: The Struggle over the Past in Zimbabwe." Journal of Southern African Studies 30 (2): 215-34. 
- 2004b. "The Uses and Abuses of History in Zimbabwe." Paper presented at the conference "Looking to the Future: Social, Political and Cultural Space in Zimbabwe,” Nordic Africa Institute, Uppsala, May 24-26.

Rubin, Barry. 2001. "The Military in Contemporary Middle East Politics.” Middle East Review of International Affairs 5 (1): 47-63.

Rupiya, Martin. 2011. “The Military Factor in Zimbabwe's Political and Electoral Affairs." www.swradioafrica.com.

Sapa-dpa. 2008. "Army Must Vote Against Tsvangirai." May 31. www.politicsweb.co.za.

Sarkesian, Sam, and Robert Conor, Jr. 2006. The US Military Profession into the TwentyFirst Century: War, Peace and Politics. 2nd edition London: Routledge.

Tachau, Frank, and Metin Heper. 1983. "The State, Politics, and the Military in Turkey." Comparative Politics 16 (1): 17-33.

Tendi, Miles. 2008. "Patriotic History and Public Intellectuals Critical of Power." Journal of Southern African Studies 34 (2): 379-96.

- 2013. "Ideology, Civilian Authority and the Zimbabwean Military." Journal of Southern African Studies 39 (4): 829-43.

Tripp, Aili Mari. 2010. Museveni's Uganda: Paradoxes of Power in a Hybrid Regime. Vol. 6. Boulder, Colo.: Lynne Rienner.

Ulio, James. 1941. "Military Morale.” American Journal of Sociology 47 (3): 312-30.

Voice of America. 2011. "Zimbabwe Army Chief Calls Prime Minister Tsvangirai a Security Threat." www.voazimbabwe.com.

Weber, Max. 1978. Economy and Society: An Outline of Interpretive Sociology. Berkeley: University of California Press.

Weingrod, Alex. 1968. "Patrons, Patronage, and Political Parties." Comparative Studies in Society and History 10 (4): 377-400.

White, Louise. 2007. "Whoever Saw a Country with Four Armies?: The Battle of Bulawayo Revisited." Journal of Southern African Studies 33 (3): 619-31.

Woodward, Rachel, and Neil Jenkings. 2011. "Military Identities in the Situated Accounts of British Military Personnel.” Sociology 45 (2): 252-68.

Young, Eric. 1997. "Chefs and Worried Soldiers: Authority and Power in the Zimbabwe National Army.” Armed Forces E Society 24 (1): 133-49. 